\title{
As the Prince of Wales, so the
}

\section{Non-Proliferation Treaty}

Across the wires the electric message came:

'He is no better, he is much the same.'

$$
\begin{aligned}
& \text { On the Illness of the Prince of } \\
& \text { Wales, afterwards Edward VII }
\end{aligned}
$$

Attributed to Alfred Austin (1835-1913)

THE Geneva conference to review the working of the Non-Proliferation Treaty ended last weekend after four frustrating weeks in which relatively little apparent success was evident. Hopes that at last the pressure of a deadline might bring the ninety-odd nations to agreement on something substantial came to nothing. Nor even did there seem to be enough in prospect for the conference to adopt the recent European expedient of stopping the clock to allow more time for discussion. Not for the first time has it been noticeable that the only thing more sacred than an international nuclear treaty is an international airline reservation!

If there is disappointment that the review conference did little to make the treaty look more attractive to the nations still outside its orbit (and it must be said that none of the potentially nuclear non-signatories is likely to be lured into the fold in the foreseeable future), this disappointment must be tempered with an element of relief that the participants did manage to stick together and that there were no defections from the treaty.

It was expected that the nuclear powers, particularly the superpowers, would have an uncomfortable month, and much of the first week or so was taken up with trying to spot who was going to emerge as the standard-bearer of the non-aligned and scourge of the nuclear powers. Eventually it was Mexico which assumed this role and took the strongest line, but the hands of the non-aligned were tied by the failure of many of the signatories among the developing countries to appear at the conference. Thus the two-thirds majority which can so often be mustered in United Nations circles against the developed countries was not easily available. Even so, Mexico's mark was firmly left on such issues as the continuing need to negotiate a comprehensive test ban and the possibility of declarations on non-first-use and non-use of nuclear weapons against non-nuclear powers.

The activities of Mrs Thorsonn, the Swedish president of the meeting, came in for much praise. She delayed her intervention with a draft document until half way through the last week when there was growing despair that anything would emerge at all, particularly from Committee 1 , charged with reviewing articles devoted to security assurances, measures for disarmament and nuclear-free zones, yet bogged down on procedural matters. Her draft found wide acceptance and eventually led to a consensus statement accompanied, not surprisingly, by a number of reservations from individual nations.

The nuclear powers could have good cause to feel pleased that they had emerged relatively unscathed from their time in the dock (they did have the advantage, one observer noted, of acting simultaneously as judge and jury).

Not so pleased were one or two other countries. Switzerland, Yugoslavia and Romania all made noises about being surrounded by countries armed with tactical nuclear weapons. With good cause did they fear that in time of crisis they might be trampled on without the superpowers caring too much. The most likely to take this complaint further is Yugoslavia and judging by the performance of the last week or so, the possibility of Yugoslavia's withdrawal from the treaty has seriously to be reckoned with. The pioneering work of India in finding a justification for nuclear development through the peaceful explosions route could handily be used by several nations in danger of being overrun.

There are, nevertheless, several positive things to have emerged from Geneva. The cause of international control both of nuclear fuel reprocessing centres and of peaceful nuclear explosion facilities has advanced considerably as a result of the conference. The concept of nuclear-free zones has been extensively aired, even if for the present only Africa seems likely to be a possible candidate for joining Latin America in this category. And there is to be a further review conference in 1980 , preceded by an examination in two years' time at the General Assembly of the United Nations of progress in fulfilling the objectives of the treaty.

If this sounds like modesty in the extreme in advancing the cause of arms control, it is, and many will go away fearing that the treaty will only continue to hold together as long as it places no serious demands on its signatories. Perhaps the treaty is too big in its sweep to be able to survive indefinitely. The real paths of progress in the next few years may be back in more detailed fields-regional treaties, restraints on testing and controls on the transfer of material. 